DOI 10.37882/2223-2982.2021.02-2.26

\title{
ИДИОМАТИЧНОСТЬ СЕМАНТИКИ СУФФИКСАЛЬНЫХ ИМЕН СУЩЕСТВИТЕЛЬНЫХ
}

\section{IDIOMATIC SEMANTICS OF SUFFIX NOUNS}

\section{Osilbekova}

Summary: The definition and classification of derived words meanings components that are not expressed by their derivational structure remains one of the unsolved problems of words formation. The study of this problem is important for the lexical semantics and lexicographic representation of derived words. The article is devoted to the idiomatic meanings of suffix nouns. It contains the characteristic of additional semantics components main types and the determination of their regularity.

Keywords: derivative word, suffix, idiomatic semantics, additional component.

\author{
Осильбекова Дания Алтмишбаевна \\ Д.филол.н., профессор, Московский педагогический \\ государственный университет \\ osilbekova@list.ru
}

Аннотация: Определение и классификация компонентов значения производных слов, не выраженных их словообразовательной структурой, остается одной из нерешенных проблем словообразования. Исследование этой проблемы важно для лексической семантики и лексикографической репрезентации производных слов. Статья посвящена идиоматичности значений суффиксальных имен существительных. Дается характеристика основных типов дополнительных семантических компонентов, определяется их регулярность.

Ключевые слова: производное слово, суффикс, идиоматичность семантики, дополнительный компонент.

Таким образом, производные с модификационным значением обозначают реалию, такую же, как и реалия, названная производящим словом, но видоизмененную. Например, у суффиксальных существительных: «то же самое, что названо производящей основой, но женского пола» (солист - солистка); «то же самое, но невзрослое» (мышь - мышонок); «то же самое, но единичное» (песокпесчинка); "то же самое, но во множестве» (колоннаколоннада). Модификационные значения имеют также производные со значениями субъективной оценки: «ласкательность» и «уменьшительность» (дом - домик, рука - рученька), «увеличительность» (дом - домище, рука-ручища).

Также к словам с неидеоматичной семантикой относятся производные с транспозиционным значением. Например: чистить - чистка «действие по производящему глаголу», молодой - молодость «отвлеченный признак по производящему прилагательному». Конечно, речь идет о прямых значениях производного и производящего. В переносных значениях появляются дополнительные семы.

У производных с мутационным значением также могут отсутствовать дополнительные компоненты. Как отмечает О.П. Ермакова, «это многочисленная группа слов, мотивированных глаголами разнообразной семантики, но объединенных тем, что все они не предполагают определенного деятеля, постоянно или профессионально связанного с действием. Поэтому такие отглагольные существительные обозначают любое лицо. Ср. оскорби- 
тель, мучитель, мститель, утешитель, обидчик, заступник, защитник, страдалец, шалун, претендент и Т.д.» $[1$, с. 61].

Проблема идиоматичности (фразеологичности) семантики производных слов давно обсуждается в лингвистике. Термин «фразеологичность семантики» был предложен М.В. Пановым [4, с. 147]. В работах о семантических проблемах словообразования отмечалось, что идиоматичность семантики в большей степени присуща именам существительным, а ее причины могут крыться в многозначности производящего слова, в многозначности СА, в мотивации комплексным наименованием, в стилистических компонентах значения $[2,3]$. Также исследователи разграничивали лексические и грамматические дополнительные компоненты (наращения) $[2,5]$.

На наш взгляд, в классификации дополнительных компонентов важно различать их отнесенность к мотивирующей части значения производного слова и отнесенность к его формантной части. Также дополнительные компоненты различаются степенью обобщенности семантики и регулярностью.

Рассмотрим типы дополнительных значений суффиксальных имен существительных с конкретным значением. Наиболее регулярными являются разновидности общепредметного значения суффиксального форманта: «лицо (мужчина, женщина, субъект, объект, совокупность)», «животное (самец, самка, субъект, объект, совокупность),» «предмет (место, вместилище, орудие, объект, субъект, результат, вещество, совокупность и др.)». Эти значения могут быть семантическими подтипами СТ. Например, СТ отсубстантивных производных с суффиксом -ник/-атник/-арник/-овник имеют общепредметное значение, обусловленное семантикой форманта. Внутри СТ выделяются семантические подтипы названий лиц (барышник, завистник, фокусник), предмета: вместилища (салатник, соусник, чайник), помещения (ледник, коровник, обезьянник), места и совокупности (ельник, ракитник, цветник) и др.

К более конкретным дополнительным компонентам формантной части семантики названий лица, относятся следующие уточняющие семы.

1. «Профессия». В русском языке отсутствуют СТ, состоящие из названий лиц по профессии. Обычно такие слова входят в СТ или отдельный семантический подтип со значением «лицо - производитель действия». Это производные с суффиксальными формантами: -тель (надзиратель, писатель, преподаватель), -щик/-чик (лепщик, летчик, сборшик), -льщик (красильщик, носильщик, прядильщик), -ец/-енец (певец, продавеи, снабженеи), -арь (пекарь, токарь), -ор (гравер, дирижер, контролер).
Более широко компонент «профессия» представлен в семантике отсубстантивных названий лица с суффиксами: -ник (колбасник, молочник, мясник), -щик/-чик/-овщик (водопроводчик, обувщик, сверловщик), -ак (моряк, рыбак), -ач (скрипач, трубач), -арь (аптекарь библиотекарь, виноградарь), -атор/-тор/-итор (авиатор, композитор, инспектор), -ар (овчар, бочар), -ист (журналист, массажист, тракторист), -ик (ботаник, историк, химик), -ант (лаборант, коммерсант, музыкант), -ор (архитектор, комбайнер, скульптор).

2. Дополнительный компонент «поведение, образ жизни» присутствует в семантике немногочисленных и единичных отглагольных производных на -ик/-ник (клеветник, нытик, шутник), -ак(а) (гуляка, кривляка, служака), -с(а) (плакса, хныкса), -х(а)/ох(а) (выпивоха, растеряха), -ул(я) (воображуля, замазуля), -ш(а)/-уш(а) (вруша, растеряша), -он(а) (гулёна), -л(а) (надувала), -лк(а) (зубрилка), -уг(a) (хапуга), - - (брюзга).

3. «Временное занятие». Этот компонент представлен в семантике отглагольных производных с суффиксами: -am (делегат), -атай (ходатай), -am(ый) (вожатый), -ок (игрок).

4. Дополнительный компонент «субъект действия» содержится в семантике отсубстантивных производных с суффиксом -ак (сибиряк - «человек, который живет в Сибири», туляк, пермяк), -ник (желудочник - «человек, который страдает болезнью желудочно-кишечного тракта», сердечник - «человек, у которого болит сердце»).

5. В семантике отсубстантивных производных с суффиксом -ник/-атник имеется дополнительный компонент «любитель» (голубятник, ягодник, окказ.: арбузник).

6. Дополнительный компонент «национальность» присутствует в семантике отсубстантивных производных с суффиксом -ец/-инеи (азербайджанеи, кубинец, эстонец), -ак (поляк, австрияк).

7. Дополнительный компонент «невзрослость» имеют отадъективные производные с суффиксом -иш: малыш, глупыш, дурныш, найденыш, несмышленыш, крепыш, последыш.

В семантике производных с предметными значениями выделяются различные дополнительные компоненты. Так, значительное количество отглагольных существительных со значением «место действия» имеют следующие дополнительные компоненты, относящиеся к мотивирующей части значения.

1. «Сопутствующее действие». Производящий глагол называет одно из возможных действий, например: раздевалка - «помещение, где раздеваются, переодеваются и хранят одежду», склад - «помещение, где складывают и хранят что-либо»,

2. Дополнительный компонент может сужать (уточ- 
нять) действие мотивирующего глагола, называя:

1) «объект действия», этот компонент присущ многим производным на -льн(я): давильня - «помещение, где давят виноград или другие плоды», красильня - «место (мастерская или цех), где красят ткани», плавильня - «помещение, где плавят металл»;

2) «субъект действия»: жилье - «место, помещение, где живут люди», кормежка - «место, где кормятся дикие животные», лежбище - «место, где лежат стадами некоторые морские животные»;

3) «обстоятельство действия»: забегаловка - «заведение, куда можно ненадолго «забежать», чтобы перекусить или выпить», остановка - «место, где останавливается транспорт для посадки и высадки пассажиров».

3. Дополнительный компонент мотивирующей части значения «ранее» содержится в семантике отсубстантивных названий места с суффиксом -иш(е): городище - «место, где раньше был город», кострище - «место, где ранее горел костер», пожарище - «место, где ранее был пожар».

Дополнительные компоненты, уточняющие формантную часть значения названий неодушевленных предметов, разнообразны. Приведем некоторые из них:

1. Отсубстантивные производные с суффиксом -ин(a) имеют дополнительные компоненты значения «вещество» (пушнина, древесина, белковина), «вид мяса» (дичина, свеженина, солонина).

2. Дополнительный компонент «часть целого» содержится в семантике отсубстантивных производных с суффиксами овище/-евище (ножевище, серповище, молотовище), -иц(а)/-ниц(а) (луковица, маковица, грибница). Этот же компонент содержится в семантике существительных, образованных от счетных прилагательных с помощью суффикса -ин(а): четвертина, пятина, десятина.
3. Дополнительные компоненты «блюдо» и «кондитерское изделие» имеют отсубстантивные и отадъективные производные на -ик/-ник: рассольник, свекольник, холодник; манник, сметанник, творожник.

Наиболее идиоматичную семантику имеют имена существительные, образованные с помощью универбации - очень продуктивного способа словообразования. Универбаты являются разговорными синонимами мотивирующего словосочетания и, как правило, образуются с помощью суффиксов -к(а) и -ик/-ник. Например: удалёнка - удалённая работа или учеба, санкционка - санкционная продукция, мобильник - мобильный телефон, отрывник - отрывной календарь. Идиоматичность семантики таких производных обусловлена очень широкой семантикой суффиксального форманта - «нечто, обладающее признаком, названным производящим прилагательным». Дополнительные компоненты их значений могут быть выделены на высоком уровне абстракции: «лицо» (грудник - грудной ребенок, подсобник - подсобный рабочий), «предмет» (дождевик - дождевой плащ, сгущенка - сгущенное молоко), «действие» (кругосветка - кругосветное плавание, рукопашка - рукопашный бой), «отвлеченное непроцессуальное значение» (жилищка - жилищное право, упрощенка - упрощенный налоговый режим)[7].

Таким образом, определение дополнительных компонентов и их классификация помогает понять природу семантики производных слов: соотношение внутренней формы слова и его лексического значения, какие имплицитные смыслы сопутствуют формально выраженным значениям или уточняют их. Дополнительные компоненты, конкретизирующие значение суффиксального форманта, свойственны и названиям лиц, и названиям предметов. Дополнительные компоненты, относящиеся к мотивирующей части семантики, в большей степени присущи названиям места действия.

\section{ЛИТЕРАТУРА}

1. Ермакова, 0.П. Фразеологичность семантики производных слов различных словообразовательных структур // Актуальные проблемы русского словообразования, 1. - Ташкент, 1975. - С. 57-63.

2. Ермакова, 0.П. Лексические значения производных слов в русском языке. - М.: Русский язык, 1984. - 152 с.

3. Земская, Е.А. Словообразование как деятельность. - М.: Наука, 1992. - 220 с.

4. Панов, М.В. 0 слове как единице языка. - В кн.: Ученые записки Московского городского педагогического института им, Потемкина. - Т. 51. - Вып. 5. M., 1956.

5. Петрова, 0.0. Изучение семантики производных слов // Преподаватель XXI век. - 3. - 2017. - С. 343-347.

6. Русская грамматика. - Т. 1. - М.: Наука, 1980. - 789 с.

7. Осильбекова, Д.А. Идиоматичность семантики универбатов // Русистика без граници. - № 1. 2020. - София. - С. 17-21.

(c) Осильбекова Дания Алтмишбаевна (osilbekova@list.ru).

Журнал «Современная наука: актуальные проблемы теории и практики» 